\title{
O mundo perdido e sempre achado de Lúcio Cardoso
}

Emil de Castro

Escritor

$\mathrm{N}$

ão vejo outro jeito de escrever sobre o Lúcio Cardoso, no momento, a não ser registrar a sua passagem por Mangaratiba, em dois tempos diversos. No início de sua vida, quando ele descobriu o mar e depois quando ele retornou à sua viagem no passado.

A sua descoberta do mar se deu de forma mágica e poética, como ele narra num artigo com que ele inaugurava, a convite de uns amigos, o jornal da mesma Mangaratiba que serviu de tema para Machado de Assis escrever "Missa do Galo", um dos seus mais belos contos e onde Mário Peixoto filmou Limite, essa jóia cinematográfica que encerraria o cinema mudo com chave de ouro.

"Foi há muitos anos atrás que travei relaçôes com o ramal de Mangaratiba - quando ainda ia pelos meus sete anos de idade, e mal acabava de descer a serra, vindo de Minas Gerais. Essa imagem distante o poeta Manuel Bandeira gravou-a já num traço indelével, em poema, que toda a gente conhece: ${ }^{1}$

- Que foi? indagou Cardoso desembarcando de um trem..."2

Lúcio Cardoso conta que desembarcou de um trem e entrou noutro e veio parar em Itacuruçá, onde morava uma tia, irmã de seu pai e que ele nunca vira, da mesma forma que nunca vira o mar. Ele imaginava o mar apenas com a sua fantasia de mineiro, "inflada pela fantasia nata do meu temperamento", como ele escrevia: "Imaginava-o como? Como uma água parada e morta, bem diferente das diferentes águas dos rios que eu tanto

\footnotetext{
${ }^{1}$ CARDOSO, 22/3/1961, p. 2.

${ }^{2}$ Apud CARDOSO, 22/3/1961, p. 2. Lúcio comete alguns erros na transcrição desses versos: “- 'Que foi?' indagou Cardoso / Desembarcando de um trem." (BANDEIRA, s/d., p. 98). [Nota dos organizadores]
} 
amava. E na verdade bem diferente desse mar que eu via agora: um mar quente, onduloso, cheio de ilhas verdes e que a determinadas horas do dia vinha mansamente lamber a calçada da única rua de Itacuruçá”. ${ }^{3}$

Nesta belíssima e inédita viagem que ele disse ser a um mundo perdido e sempre achado, mundo a que ele voltaria outras vezes e que o marcou profundamente, como ele revela nas páginas de seu diário, ${ }^{4}$ sua chama poética se acenderia com toda força. Diz ele: "Um dia voltei ao ramal: aluguei uma casa em Filgueiras. Assim conheci Ibicuí, Muriqui, Mangaratiba. Assim vi partir as lanchas para esses condados que não conheço ainda: Parati e Angra dos Reis. Parati de quem Dorival Caymmi me fala com tanto entusiasmo, Angra dos Reis, onde Joel Silveira costuma passar seus sábados de descanso." 5

"Comecei a desfiar o rosário do princípio: Coroa Grande (com o ritmo da precisa de Mário Peixoto soando em meus ouvidos: 'Choveu na serra, Bibiana, choveu em Coroa Grande...') até o ponto extremo, onde a pequena capela olha a estação e o mar, com seu velho friso de azulejos portugueses: Mangaratiba."6

E conclui o grande romancista de Crônica da Casa Assassinada: "Vale a pena dizer tudo o que vi, tudo o aprendi?

Trens da madrugada, trilhos, essa nostalgia de uma viagem feita permanentemente, à beira-mar. Olho e sinto: no espaço em que também viajo através do tempo, até essa infância, que permanece transida com o seu primeiro susto diante da maré que vem subindo, sinto, eterno, esse perfume que me acompanhará para sempre, peixe, mar, carvão e lírio selvagem, síntese desse mundo que se constrói cheio de prodigiosa beleza entre a montanha e o mar." ${ }^{\prime}$

Neste mesmo ano, após a publicação da crônica naquele jornal, ele voltaria ao Município, em agosto, como registraria no seu diário, em $1^{\circ} \mathrm{de}$ agosto de 1961: "Escrevo estas linhas em Muriqui, onde já estive, neste ramal de Mangaratiba onde tanto já vim pelo passado." " A fantástica viagem continua. No dia 13 de agosto do mesmo ano, véspera de seu aniversário,

\footnotetext{
${ }^{3}$ CARDOSO, 22/3/1961, p. 2.

${ }^{4}$ Ver CARDOSO, 1970, p. 279 e seguintes.

${ }^{5}$ CARDOSO, 22/3/1961, p. 2.

${ }^{6}$ CARDOSO, 22/3/1961, p. 2.

${ }^{7}$ CARDOSO, 22/3/1961, p. 2.

${ }^{8}$ CARDOSO, 1970, p. 279.
} 
encontrava-me lecionando numa sala de aula, no nosso primeiro e único ginásio, na época, quando recebi o recado de um aluno, de que ele desejava me conhecer, por ter ouvido dizer que eu escrevia poesia. E lá fui eu conhecer o primeiro e grande romancista de minha vida. Escritores, de fato e de direito, só os conhecia nos livros. Levei para ele o meu primeiro caderno de poemas, manuscritos, alguns já publicados num jornal mimeografado do ginásio, chamado $O$ Marimbondo e onde Elio Gaspari fez sua iniciação jornalística. Lúcio leu meus poemas, na mesa de um bar, e me deu minhas primeiras liçôes de arte poética, uma espécie de conselho a um jovem poeta. É como ele registrou no seu Diário Completo: "13 - Escrevo isto em Mangaratiba, à espera do meu aniversário. Se tivesse um conselho a dar, qual seria este conselho? É terrível, mas na minha idade, neste sentido, nada tenho a dizer, conselho nenhum a dar. Viver, não tenho medo de viver, como disse num programa de televisão. Mas a minha audácia é feita de medo de viver, já tenho medo, não tenho mais nada. Que dizer, que derramar no sentido clássico de 'conselho a um jovem poeta'? Não sei nada. Não sei de nada. Sinto-me tão tumultuado e tão confuso como se estivesse começando tudo."

No mesmo dia, o romancista torna a mergulhar no passado: "Agora, entre nós dois, Ibicuí.

Este nome, na sua grafia antiga - Ibicuhy - é o mesmo que vi vibrar há mais de vinte anos passados, pela primeira vez, no alto de uma carta de Mário Peixoto. (Procurei a carta: creio que há nela, implícita, uma descrição desta pequena cidade onde me acho agora.) Depois conheci Ibicuí. Depois, passou a se fixar no meu itinerário íntimo, como um desses lugares dolorosos, estranhos, inadmissíveis, para onde vão sempre os que amo, mas onde, infelizmente, nunca sou admitido. Agora um novo Ibicuí reponta: agora é simples e sem turbação o que existe. Um pouco afeito, sondo-o, reflito, comparo suas pequenas luzes - e nem de longe se parece com o sonho distante e a parte que sempre trouxe comigo." 10

No dia 14, Lúcio Cardoso continua a compor seu poema de amor pela cidade que ele conheceu aos sete anos de idade, esse mundo perdido e que ele tornou a achar: "A ti revejo, Mangaratiba. A baía aberta, o recortado das montanhas, e o sol. Como me sinto aqui como sempre me senti: entendo os

${ }^{9}$ CARDOSO, 1970, p. 284-285.

${ }^{10}$ CARDOSO, 1970, p. 285. 
trens e os barcos. Trilhos, cheiro de graxa. Não me envelheço e nem me diminuo: cresço, pelos lados decompostos de sombras e arestas. Nisto não há noite por onde olho, o tumulto me enche e me acorda. O que olha por mim são sempre olhos de menino. De súbito, desvendo: o mar existe. Este óleo, este cheiro errante, camarôes, peixes, a fumaça de um barco. Por mim, sei - é o mar. Por dentro, por fora, um azul fosco e morno me envolve - incendiado, o dia fita." ${ }^{11}$

Seu poema, porém, ainda não se concluiu. No dia seguinte, é que ele revela a estranha noite de seu aniversário, o grande fecho de um poema que se iniciou aos sete anos de idade, quando ele viu o mar pela primeira vez e que o escravizaria por toda vida: a tragédia de sua vida: "Foi ontem a mais estranha noite de aniversário da minha vida. Depois de esperar em vão pessoas que não vieram, jantei entre $\mathrm{D}$. Blandina, que me hospeda, e duas senhoras que não conheço. Consegui arranjar um vaso de avencas para enfeitar a mesa - e efetuamos os brindes usuais, enquanto lá fora Mangaratiba ressoava cheia de gritos e de luzes." 12

Sua viagem por estas paragens não terminaria aí, mas, ao contrário, continuaria através de suas pinturas: os barcos, as sombras, os traços da estação e dos trilhos que ele tanto amava, as luzes, as cores, azuis, verdes, o mar quente, onduloso, cheio de ilhas. Foi nesta época que Lúcio Cardoso fez a sua última viagem a um outro mundo perdido e sempre achado.

Mangaratiba, 2 de maio de 2008

\section{Referências Bibliográficas}

BANDEIRA, Manuel. Os voluntários do norte. In: Libertinagem \& Estrela da manhã. 2. ed. Rio de Janeiro: Nova Fronteira, s/d. p. 98-99.

CARDOSO, Lúcio. Um mundo perdido e sempre achado. Correio de Mangaratiba, Mangaratiba, RJ, 22 mar. 1961. Ano I, n. 1, p. 2.

. Diário completo. Rio de Janeiro: José Olympio/INL, 1970.

\footnotetext{
${ }^{11}$ CARDOSO, 1970, p. 287.

${ }^{12}$ CARDOSO, 1970, p. 287.
} 


\section{Resumo}

Este texto relata as duas visitas que Lúcio Cardoso faz a Mangaratiba, no Estado do Rio de Janeiro.

\section{Abstract}

This text reports two visits which Lúcio Cardoso does the Mangaratiba, in the State of the Rio de Janeiro. 